\title{
Spatial differentiation of marine eutrophication damage indicators based on species density
}

Cosme, Nuno Miguel Dias; Jones, Miranda C.; Cheung, William W. L.; Larsen, Henrik Fred

Published in:

Ecological Indicators

Link to article, DOI:

10.1016/j.ecolind.2016.10.026

Publication date:

2016

Document Version

Peer reviewed version

Link back to DTU Orbit

Citation (APA):

Cosme, N. M. D., Jones, M. C., Cheung, W. W. L., \& Larsen, H. F. (2016). Spatial differentiation of marine eutrophication damage indicators based on species density. Ecological Indicators, 73, 676-685.

https://doi.org/10.1016/j.ecolind.2016.10.026

\section{General rights}

Copyright and moral rights for the publications made accessible in the public portal are retained by the authors and/or other copyright owners and it is a condition of accessing publications that users recognise and abide by the legal requirements associated with these rights.

- Users may download and print one copy of any publication from the public portal for the purpose of private study or research.

- You may not further distribute the material or use it for any profit-making activity or commercial gain

- You may freely distribute the URL identifying the publication in the public portal 


\title{
Spatial differentiation of marine eutrophication damage indicators based on species density
}

\author{
Nuno Cosme ${ }^{1 *}$, Miranda C. Jones ${ }^{2}$, William W. L. Cheung ${ }^{3}$, Henrik Fred Larsen ${ }^{1}$ \\ ${ }^{1}$ Division for Quantitative Sustainability Assessment, Department of Management Engineering, Technical \\ University of Denmark, Produktionstorvet 424, DK-2800 Kgs. Lyngby, Denmark \\ ${ }^{2}$ United Nations Environment Programme World Conservation Monitoring Centre, 219 Huntingdon Road, \\ Cambridge CB3 ODL, UK \\ ${ }^{3}$ Changing Ocean Research Unit and Nippon Foundation - Nereus Program, Institute for the Oceans and \\ Fisheries, the University of British Columbia, Vancouver, British Columbia, Canada \\ *Corresponding author: e-mail address: nmdc@dtu.dk; nmcosme@gmail.com (N. Cosme)
}

\begin{abstract}
Marine eutrophication refers to an ecosystem response to the loading of nutrients, typically nitrogen $(\mathrm{N})$, to coastal waters where several impacts may occur. The increase of planktonic growth due to $\mathrm{N}$-enrichment fuels the organic carbon cycles and may lead to excessive oxygen depletion in benthic waters. Such hypoxic conditions may cause severe effects on exposed ecological communities. The biologic processes that determine production, sink, and aerobic respiration of organic material, as a function of available $\mathrm{N}$, are coupled with the sensitivity of demersal species to hypoxia to derive an indicator of the Ecosystem Response (ER) to N-uptake. The loss of species richness expressed by the ER is further modelled to a marine eutrophication Ecosystem Damage (meED) indicator, as an absolute metric of time integrated number of species disappeared (species·yr), by applying a newly-proposed and spatially-explicit factor based on species density (SD). The meED indicator is calculated for 66 Large Marine Ecosystems and ranges from $1.6 \times 10^{-12}$ species $\cdot \mathrm{kgN}^{-1}$ in the Central Arctic Ocean, to $4.8 \times 10^{-8}$ species $\cdot \mathrm{kgN}^{-1}$ in the Northeast U.S. Continental Shelf. The spatially explicit SDs contribute to the environmental relevance of meED scores and to the harmonization of marine eutrophication impacts with other ecosystem-damage Life Cycle Impact Assessment (LCIA) indicators. The novel features improve current methodologies and support the adoption of the meED indicator in LCIA for the characterization of anthropogenic-N emissions and thus contributing to the sustainability assessment of human activities.
\end{abstract}

Keywords Exposure $\cdot$ Effect $\cdot$ Life Cycle Impact Assessment $\cdot$ Ecosystem damage $\cdot$ Large Marine Ecosystems $\cdot$ Potentially Affected Fraction of Species

\section{Table of contents}

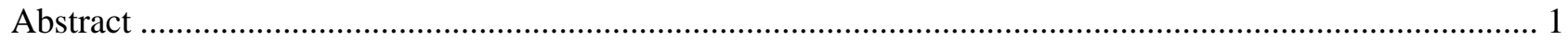

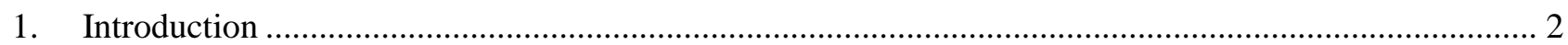

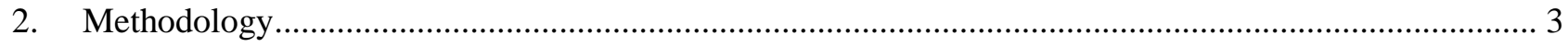

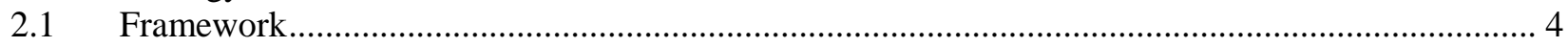

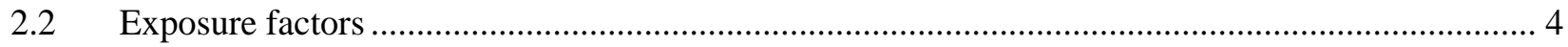

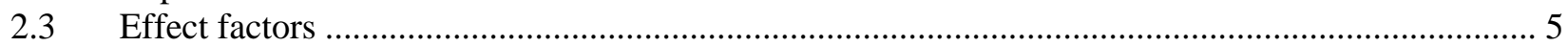

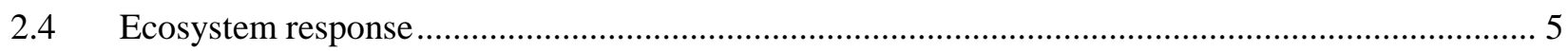

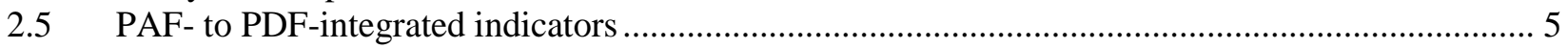




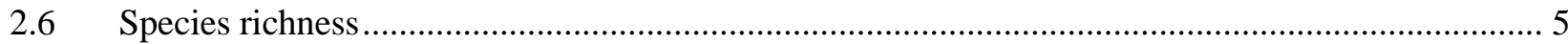

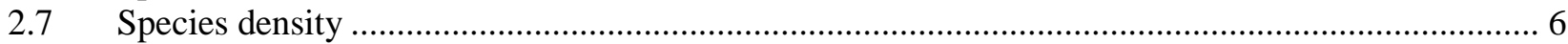

2.8 Spatially explicit absolute metric of damage to ecosystems ........................................................ 6

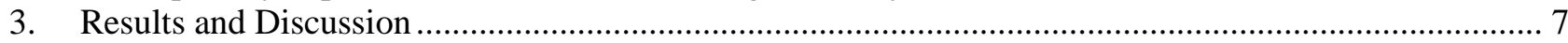

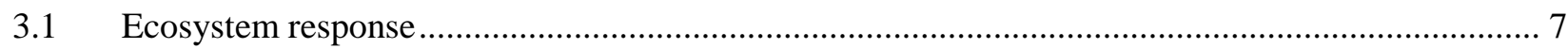

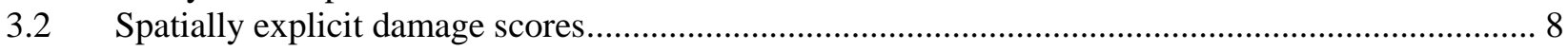

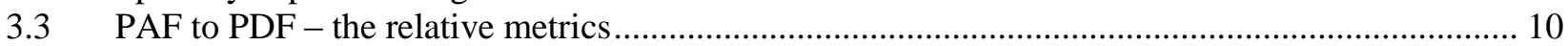

3.4 Harmonization of damage indicators - the absolute metrics ................................................ 11

3.5 Spatial resolution and LME biogeographical classification system .................................................. 12

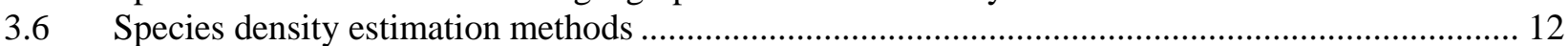

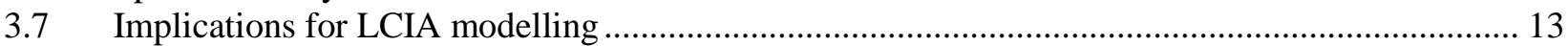

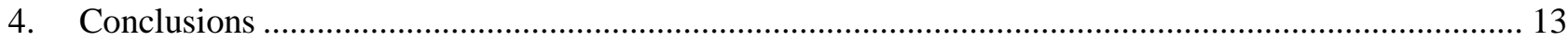

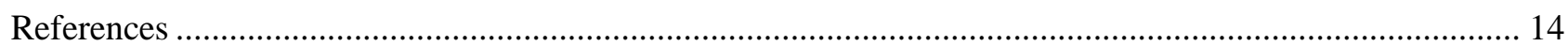

\section{List of abbreviations}

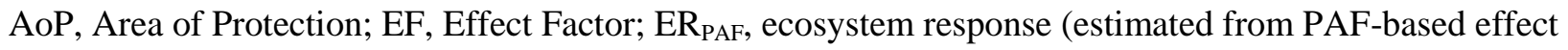
factors); $\mathrm{ER}_{\mathrm{PDF}}$, Ecosystem Response (estimated from PDF-based effect factors); LCIA, life cycle impact assessment; LME, large marine ecosystem; meDF, marine eutrophication damage factor; meED, marine eutrophication ecosystem damage; PAF, potentially affected fraction of species; PDF, potentially disappeared fraction of species; SD, species density; SDM, species distribution model; SR, species richness; $\mathrm{SSD}$, species sensitivity distribution; $\mathrm{XF}$, exposure factor

\section{Introduction}

Marine eutrophication is an ecosystem response to an increased availability of a growth-limiting nutrient in the euphotic zone of coastal waters (Gray et al., 2002; Rabalais, 2002; Smith et al., 1999) and its consequences are among the most severe and widespread disturbances to marine environments (Diaz and Rosenberg, 2008; GESAMP, 2001). Nitrogen (N) is assumed to be the limiting nutrient in marine coastal waters (Howarth and Marino, 2006; Vitousek et al., 2002), acknowledging that spatial and seasonal limitation by phosphorus (P) or silicon ( $\mathrm{Si}$ ) and cases of co-limitation may occur (see e.g. Arrigo, 2005; Elser et al., 2007; Turner et al., 1998). The N-enrichment of coastal waters boosts planktonic growth, or primary production $(\mathrm{PP})$ - the photosynthetic reduction of inorganic carbon into energy-rich organic carbon involving the assimilation of inorganic dissolved plant nutrients and the utilization of light energy by primary producers, mainly phytoplankton, in the well-lit upper layers of the ocean (euphotic zone) (Chavez et al., 2011; Falkowski and Raven, 2007). The eventual aerobic respiration of this newly produced organic matter may result in oxygen depletion in bottom waters (Cosme et al., 2015; Graf et al., 1982; Ploug et al., 1999) and even in the occurrence of 'dead zones' (Diaz, 2001; Diaz and Rosenberg, 2008). Effects on exposed demersal species (e.g. fish, crustaceans, or bivalves) may then be expected as a function of their sensitivity to hypoxia (Cosme and Hauschild, 2016; Davis, 1975; Diaz and Rosenberg, 1995; Gray et al., 2002; VaquerSunyer and Duarte, 2008) and promote other impacts that may include habitat loss, water quality degradation, mass mortality, and fisheries decline (Diaz and Rosenberg, 1995; Levin et al., 2009; Middelburg and Levin, 2009; Wu, 2002; J. Zhang et al., 2010).

Globally, environmental N-emissions from human activities have increased more than 10 -fold in the last 150 years in large part due to the growing demand for reactive nitrogen in agriculture use and for energy production (Galloway et al., 2008). Considering the $\mathrm{N}$ emissions throughout the entire life cycle of products and services in the economy, Life Cycle Assessment (LCA) can be used as an environmental analysis tool designed to quantify the resulting potential impacts (Hauschild, 2005). Indicators of marine eutrophication 
impacts are estimated in the Life Cycle Impact Assessment (LCIA) phase of LCA, typically at the midpoint between emission and damage (endpoint) in the cascade of N-enrichment effects in the marine compartment (Rabalais et al., 2009). This fact is reflected in widespread LCIA methods, like ReCiPe (Goedkoop et al., 2012), EDIP 2003 (Hauschild and Potting, 2005), IMPACT 2002+ (Jolliet et al., 2003), and CML 2002 (Guinée et al., 2002). Recent reviews of the state-of-the-art and research needs regarding marine eutrophication impacts modelling revealed the lack of a consistent link between existing midpoints and damage level (Hauschild et al., 2013; Henderson, 2015). While the midpoint indicator models nutrients fate in the environment, the endpoint indicator further requires exposure and effects modelling for consistency with the generic LCIA framework (Udo de Haes et al., 2002). Recent work has developed explicit ecosystem exposure factors (XF) (Cosme et al., 2015) and effect factors (EF) (Cosme and Hauschild, 2016). An XF×EF coupled indicator represents the ecosystem response to $\mathrm{N}$-uptake by primary producers in coastal waters. Additional fate modelling may deliver the marine eutrophication impact potential of a unit mass of $\mathrm{N}$ emitted from anthropogenic sources.

Methodology-wise, other ecosystem-related LCIA indicators at the endpoint level, e.g. for ecotoxicity or acidification, can be aggregated into damage to the ecosystem, also known as an Area of Protection (AoP) (Udo de Haes et al., 1999), and be expressed as a time-integrated loss of species richness, i.e. species.yr. Such conversions currently adopt a site-generic marine species density (SD) value (Goedkoop et al., 2012) an inherent model (rough) simplification. Recent work focusing on marine species distribution (Jones and Cheung, 2015) may provide the damage modelling with site-dependent SDs to estimate environmentally relevant damage factors (DF). The present approach derives the ecosystem response (ER) indicator from the cause-effect chain triggered by $\mathrm{N}$-enrichment of coastal waters that leads to impacts on ecological communities affected by oxygen depletion. The spatial differentiation given by the exposure and effect components of the model work is further combined with the natural occurrence of the potentially affected species in coastal waters around the globe (i.e. their density, SD). Given the local to regional character of marine eutrophication and hypoxia events, this impact assessment approach seems useful for comparative purposes.

The goal of this study is to quantify spatially explicit damage potentials for $\mathrm{N}$ emissions that fuel primary production in coastal waters and thus contributing to marine eutrophication. This quantification requires (i) the derivation of an ecosystem response indicator, obtained by combining the ecosystem exposure to $\mathrm{N}$ and the effects on biota caused by hypoxia, and (ii) an additional conversion of the damage to ecosystem from relative to absolute metrics, based on site-dependent species density. The application of such method is discussed for the characterisation modelling of anthropogenic emissions of $\mathrm{N}$ with eutrophying impacts in a LCIA framework.

\section{Methodology}

The approach used here is consistent with the LCIA framework for emission-related impact indicators. It estimates potential impacts to the ecosystem by combining environmental fate of substances emissions, exposure of the receiving ecosystem to these, and the effect caused on exposed species (Pennington et al., 2004b; Udo de Haes et al., 2002) (Section 2.1). The present method proposes an indicator for the loss of species richness caused by hypoxia-based marine eutrophication expressed as a volume-integrated Potentially Affected Fraction (PAF) of species per unit mass of N uptaken (Sections 2.2-2.4). A metrics conversion to Potentially Disappeared Fraction (PDF) of species is proposed for harmonisation with other ecosystem-related endpoint indicators (Section 2.5). An additional conversion to an absolute metric is 
proposed, based on site-dependent species density obtained from marine species distribution models (Sections 2.5-2.8).

\subsection{Framework}

The LCIA factor, or Characterisation Factor $\left(C F,(\mathrm{PAF}) \cdot \mathrm{m}^{3} \cdot \mathrm{yr} \cdot \mathrm{kgN}^{-1}\right)$, that translates the quantity of an emission into its potential impact on the exposed environmental compartment (coastal marine ecosystem) is derived as summarised in Eq. (1):

$C F_{i j}=F F_{i j} \times X F_{j} \times E F_{j}$

where $F F_{i j}(\mathrm{yr})$ is the fate factor for emission route $i$ (N to air, from soil, to fresh-, or to marine water) to receiving ecosystem $j$ (coastal marine), $X F_{j}\left(\mathrm{kgO}_{2} \cdot \mathrm{kgN}^{-1}\right)$ is the exposure factor and $E F_{j}\left((\mathrm{PAF}) \cdot \mathrm{m}^{3} \cdot \mathrm{kgO}_{2}^{-1}\right)$ the effect factor, both in ecosystem $j$. PAF is included for informative reasons as it is not an actual unit but a dimensionless quantity (fraction) (Heijungs, 2005). Acknowledging the meaning and application of CFs in impact assessment, the scope of the present method is limited to the estimation of the ecosystem response to $\mathrm{N}$ uptaken by phytoplankton, for which XF and EF are applied (see Figure 1). Spatial explicit fate modelling can however be adapted for waterborne (Cosme et al., 2016) and airborne $\mathrm{N}$ emissions (Dentener et al., 2006; Roy et al., 2012).

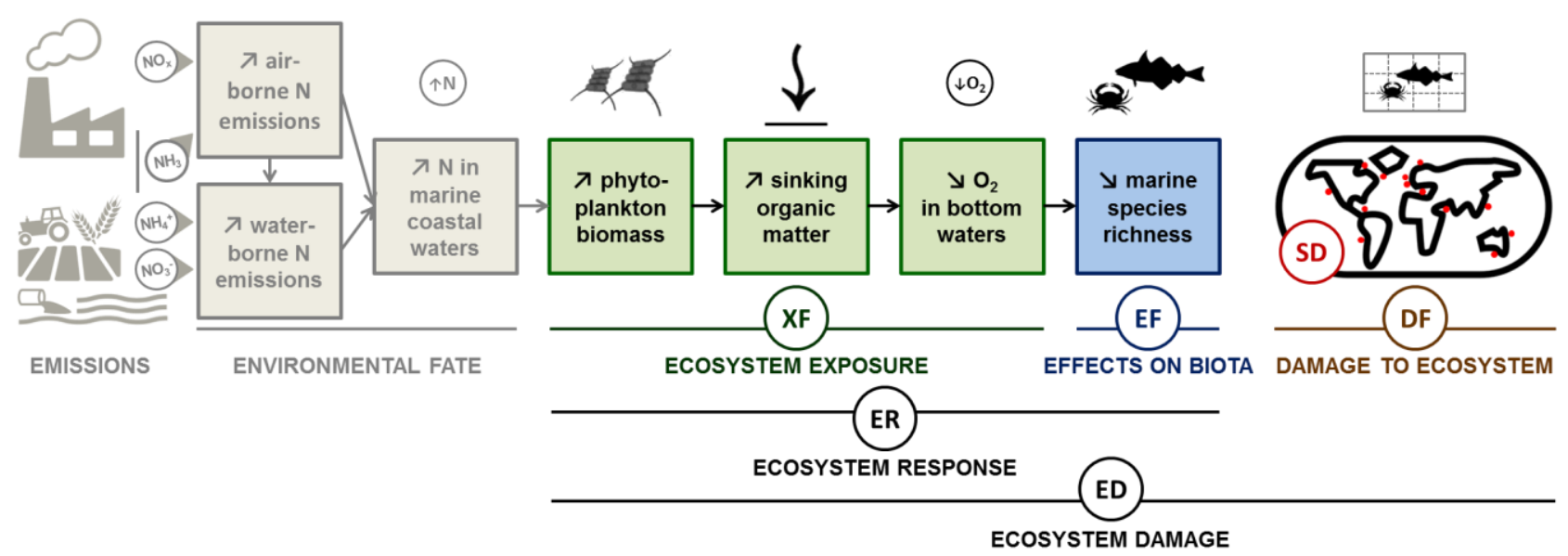

Figure 1 Schematic representation of the marine eutrophication impact pathway. Only the modelling components of ecosystem exposure and effects on biota (coloured box processes) are used to derive the ecosystem response (ER) to nitrogen uptake in the euphotic zone of coastal waters. Grey shaded boxes refer to emission-related and environmental fate processes (outside the scope of this work). The product of exposure factor (XF) and effect factor (EF) delivers an ecosystem response (ER) indicator, which is then multiplied by the spatially differentiated damage factor (DF) based on species density (SD) to derive the ecosystem damage (ED). (For interpretation of the references to colour in this figure legend, the reader is referred to the web version of this article.)

\subsection{Exposure factors}

The XF comprises the assimilation of $\mathrm{N}$ that boosts planktonic growth, followed by the export of organic carbon to bottom strata where heterotrophic bacteria consume dissolved oxygen by aerobic respiration. The model work proposed by Cosme et al. (2015) describes the biological processes of N-limited primary production (PP), metazoan consumption, and bacterial degradation, in four distinct organic carbon sinking routes. The resulting XFs, nitrogen-to-oxygen 'conversion' potentials, are available at a recommended spatial resolution of Large Marine Ecosystems (LMEs) (Sherman and Alexander, 1986) and 
range from $0.45 \mathrm{kgO}_{2} \cdot \mathrm{kgN}^{-1}$ in the Central Arctic Ocean to $16 \mathrm{kgO}_{2} \cdot \mathrm{kgN}^{-1}$ in the Baltic Sea (Figure S.1) (Cosme et al., 2015).

\subsection{Effect factors}

The EF represents the average effect of hypoxia on an exposed demersal community. It is derived from the sensitivity of the composing individual species to hypoxia, with threshold values expressed as lowestobserved-effect-concentrations (LOEC), integrated with a Species Sensitivity Distribution (SSD)

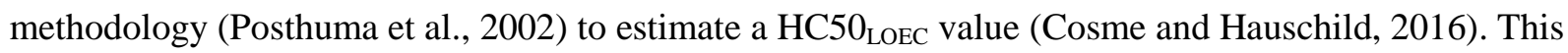
represents the intensity of the stressor, i.e. a dissolved oxygen (DO) level, at which $50 \%$ of the species are affected above their individual threshold. The $\mathrm{EF}\left[(\mathrm{PAF}) \cdot \mathrm{m}^{3} \cdot \mathrm{kgO}_{2}^{-1}\right]$ is derived as the average variation of effect ( $\triangle \mathrm{PAF}$, [dimensionless]) in the ecological community in ecosystem $j$ due to a variation of the stressor intensity $\left(\triangle \mathrm{DO},\left[\mathrm{kgO}_{2} \cdot \mathrm{m}^{-3}\right]\right)$ in the same ecosystem (Eq. 2), according to the current scientific consensus (Larsen and Hauschild, 2007; Pennington et al., 2004a):

$E F_{C \rightarrow j}=\frac{\Delta P A F_{C \rightarrow j}}{\Delta D O_{c \rightarrow j}}=\frac{0.5}{H C 50_{L O E C_{C \rightarrow j}}}$

The EF, as defined and used in LCIA, reads as the ability of an environmental stressor to cause a potential loss of species richness in the exposed ecosystem (Cosme and Hauschild, 2016). EF values are available at a five climate zone $(\mathrm{CZ})$ resolution (polar, subpolar, temperate, subtropical, and tropical) and range from $218(\mathrm{PAF}) \cdot \mathrm{m}^{3} \cdot \mathrm{kgO}_{2}^{-1}$ (polar CZ) to $306(\mathrm{PAF}) \cdot \mathrm{m}^{3} \cdot \mathrm{kgO}_{2}{ }^{-1}$ (tropical CZ) (Figure S.2). A disaggregation into $66 \mathrm{LMEs}(j)$ is possible by following the LME distribution per $\mathrm{CZ}(c)$ as a function of mean benthic water temperature (Cosme and Hauschild, 2016), and denoted in Eq. (2) as $c \rightarrow j$.

\subsection{Ecosystem response}

The ecosystem response $\left(E R,\left[(\mathrm{PAF}) \cdot \mathrm{m}^{3} \cdot \mathrm{kgN}^{-1}\right]\right)$ indicator score was calculated for every LME by multiplying the exposure (XF) and effect (EF) factors of the corresponding LME (ecosystem $j$ ), as in Eq. (3):

$E R_{P A F j}=X F_{j} \cdot E F_{j}$

\subsection{PAF- to PDF-integrated indicators}

A marine eutrophication Damage Factor (meDF) (Eq. 4) was applied to $\mathrm{ER}_{\mathrm{PAF}}$ for the metrics conversion in each ecosystem $j$ (LME) (Eq. 5) aimed at harmonisation of endpoint scores in the LCIA framework as a PDF-integrated unit (Udo de Haes et al., 1999). The aim here is meaningful comparisons and further aggregation with other indicators that also target the ecosystem AoP, designated Ecosystem Quality in the Eco-indicator 99 method (Goedkoop and Spriensma, 2000) and Impact 2002+ (Jolliet et al., 2003) method, or Ecosystems in the ReCiPe method (Goedkoop et al., 2012). See justification and discussion of $m e D F$ quantification in Section 3.3 ahead.

$$
\begin{aligned}
& m e D F=\frac{0.5(\mathrm{PDF}) \cdot \mathrm{m}^{3} \cdot \mathrm{kgN}^{-1}}{1(\mathrm{PAF}) \cdot \mathrm{m}^{3} \cdot \mathrm{kgN}^{-1}}=0.5(P D F) \cdot(P A F)^{-1} \\
& E R_{P D F j}=m e D F \cdot E R_{P A F j}
\end{aligned}
$$

\subsection{Species richness}

Three species distribution models (SDMs) were applied to predict distributions of exploited marine species - Maxent, AquaMaps and the Sea Around Us Project method. Generically, SDMs compare species 
occurrence with physical and biological conditions of the occurring areas to infer the bioclimatic envelope for the species (Hutchinson, 1957). This was attained by Maxent and AquaMaps by means of generative statistical procedures only differing on the algorithms used (Jones et al., 2012). The Sea Around Us Project method algorithm (see Cheung et al. (2008); Close et al. (2006); www.seaaroundus.org; also named Dynamic Bioclimate Envelope Model (see Jones and Cheung (2015)) estimates the relative abundance of a set of species based on the species' depth range, horizontal range, known Food and Agriculture Organization statistical areas and polygons encompassing their known occurrence regions. In this method, the distributions are further refined by assigning habitat preferences to each species, such as affinity to shelf (inner, outer), estuaries, and coral reef habitats, obtained from FishBase (www.fishbase.org) and SeaLifeBase (www.sealifebase.org). Detailed descriptions of the three SDMs are provided in the Supplementary Information of Jones and Cheung (2015) and references therein, and model validation work documented in Jones et al. (2012). Presence data were chosen to represent species occurrence for being considered more appropriate than absence data, which are likely to be inaccurate and only occasionally available for marine species (Jones and Cheung, 2015).

The SDMs were used to estimate a 20-year averaged distribution centred on 2000 (1991-2010), from presence-only occurrence data obtained from the Ocean Biogeographic System (OBIS, www.iobis.org/) on a $0.5^{\circ}$ latitude $\times 0.5^{\circ}$ longitude grid. The dataset used comprises 626 exploited benthic, demersal, and benthopelagic fish and invertebrates species (Table S.1) in the world oceans. Averaged LME-dependent species richness (SR) values were calculated by spatial aggregation in each of the 66 LME spatial units.

\subsection{Species density}

The benthic-demersal habitat was assumed as of 20 metres off the bottom on the neritic zone, corresponding to the bottom layer of the water column where demersal benthopelagic species are probable to occur (benthic species are necessarily included). This assumption is suggested by bottom trawl fisheries results, i.e. effective trawl fishing heights of 12-20 metres off the bottom for demersal species (Hjellvik et al., 2003) and 20 metres vertical trawl opening for benthopelagic species (Doray and Trenkel, 2010). This value was multiplied by the LME area to estimate the benthic-demersal habitat volume. Areal data per LME were compiled from the Sea Around Us Project (www.seaaroundus.org). The conversion of species richness (SR) values per LME $j$ into species density (SD) followed Eq. (6):

$S D_{j}=S R_{j} /\left(A_{j} \cdot h\right)$

where the species density $\left(S D,\left[\right.\right.$ species $\left.\left.\cdot \mathrm{m}^{-3}\right]\right)$ is obtained by dividing the number of occurring species, i.e. species richness $(S R)$ per LME, by the corresponding benthic-demersal habitat volume $\left[\mathrm{m}^{3}\right]$, i.e. LME area $\left(A,\left[\mathrm{~m}^{2}\right]\right)$ multiplied by the average height $(h,[\mathrm{~m}])$ of 20 metres (Table 1$)$.

\subsection{Spatially explicit absolute metric of damage to ecosystems}

As species composing coastal ecological communities vary geographically, a relative impact metric (based on PAF or PDF, i.e. fractions) of marine eutrophication impacts may therefore not be representative of the damage to local communities, for which an absolute metric would fit. Although using a site-generic $\mathrm{SD}$, a relative-to-absolute conversion approach is already applied to ecosystem-related indicators in the ReCiPe LCIA method (Goedkoop et al., 2012). A similar metric conversion is proposed in the present context to an endpoint-like indicator, i.e. the ecosystem response indicator, as this is similar to an impact potential (like a CF) but missing the magnitude given by the fate factor - which scales the impact to the actual emission it tries to characterise, rather than scaling it to a unit mass uptaken by phytoplankton. 
Therefore, the relative endpoint score was converted to an absolute one by multiplying the ecosystem response $\left(E R_{P D F},\left[(\mathrm{PDF}) \cdot \mathrm{m}^{3} \cdot \mathrm{kgN}^{-1}\right]\right)$ indicator score with a spatially differentiated $\mathrm{SD}$ [species $\left.\cdot \mathrm{m}^{-3}\right]$ in LME $j$, to deliver the marine eutrophication Ecosystem Damage (meED, [species $\cdot \mathrm{kgN}^{-1}$ ]), as per eq. (7):

$m e E D_{j}=E R_{P D F j} \cdot S D_{j}$

The meED expresses an absolute measure of the ecosystem damage potential per LME. Further aggregation is then possible into a damage category, i.e. AoP. Worth of mention here is the fact that, to the knowledge of the authors, there is no available and recommended method for endpoint modelling of a marine eutrophication indicator (Hauschild et al., 2013; Henderson, 2015), as also noted by the International Reference Life Cycle Data System (ILCD) (EC-JRC, 2010).

\section{Results and Discussion}

\subsection{Ecosystem response}

Ecosystem response (ER) scores were calculated for the 66 LMEs according to Eq. (3) to represent the average impact of the uptake of a unit mass of $\mathrm{N}$ by phytoplankton in the LME's euphotic zone - the results are given in the respective column in Table 1 and its distribution shown in Figure S.3. The ER $_{\mathrm{PAF}}$ scores range from $98.16(\mathrm{PAF}) \cdot \mathrm{m}^{3} \cdot \mathrm{kgN}^{-1}$ (in LME\#64 Central Arctic Ocean) to $3,853(\mathrm{PAF}) \cdot \mathrm{m}^{3} \cdot \mathrm{kgN}^{-1}$ (in LME\#23 Baltic Sea). The $\mathrm{ER}_{\mathrm{PAF}}$ variation per LME is correlated with $\mathrm{XF}_{\mathrm{LME}}(r=0.98)$, which in turn is strongly correlated to primary production (PP) rates (Cosme et al., 2015), both sharing a 66 LME spatial resolution. The lower spatial variability expressed by only 5 climate zones in the $\mathrm{EF}_{\mathrm{LME}}$ renders a smaller and inverse correlation $(r=-0.20)$ to $\mathrm{ER}_{\mathrm{PAF}}$. Such correlations do not alter the ranks of the lowest four and highest six scoring LMEs in both XF and ER indicators. As seen before, the ER is not an impact scaled to the anthropogenic emission of $\mathrm{N}$, as no environmental fate is modelled, e.g. as removal in land or freshwaterrather, it expresses the ecosystem's potential to respond to an increase in $\mathrm{N}$ availability that causes hypoxiarelated impacts on biota. Damage factors $(m e D F)$ were applied and $\mathrm{ER}_{\mathrm{PAF}}$ converted to $\mathrm{ER}_{\mathrm{PDF}}$ (results in Table 1 and Figure S.4).

Table 1 Results of the ecosystem response (ER) scores per Large Marine Ecosystem (LME), calculated from the ecosystem eXposure Factor $(X F)$ and Effect Factor $(E F)$, in both PAF- and PDF-integrated metrics. Also, results of the marine eutrophication Ecosystem Damage $(m e E D)$ scores calculated with species density $(S D)$ derived from mean species richness $(S R)$ per LME (standard deviation, $\sigma$, included). The LME area $(A)$ was used to derive the benthicdemersal habitat volume (assumed height $=20 \mathrm{~m}$ ).

\begin{tabular}{|c|c|c|c|c|c|c|c|c|c|}
\hline \multirow[t]{2}{*}{ Large Marine Ecosystem } & \multirow{2}{*}{$\begin{array}{r}X F \\
\mathrm{kgO}_{2} \cdot \mathrm{kgN}^{-1}\end{array}$} & \multirow{2}{*}{$\begin{array}{r}E F \\
(\mathrm{PAF}) \cdot \mathrm{m}^{3} \cdot \mathrm{kgO}_{2}{ }^{-1}\end{array}$} & \multirow{2}{*}{$\begin{array}{r}E R_{P A F} \\
(\mathrm{PAF}) \cdot \mathrm{m}^{3} \cdot \mathrm{kgN}^{-1}\end{array}$} & \multirow{2}{*}{$\begin{array}{r}E R_{P D F} \\
(\mathrm{PDF}) \cdot \mathrm{m}^{3} \cdot \mathrm{kgN}^{-1}\end{array}$} & \multicolumn{2}{|c|}{$S R$} & \multirow{2}{*}{\multicolumn{3}{|c|}{$\begin{array}{ccr}A & S D & m e E D \\
\mathrm{~km}^{2} & \text { species } \cdot \mathrm{m}^{-3} \text { species } \cdot \mathrm{kgN}^{-1}\end{array}$}} \\
\hline & & & & & species & $\sigma$ & & & \\
\hline 01. East Bering Sea & 9.86 & 242 & $2.38 \mathrm{E}+03$ & $1.19 \mathrm{E}+03$ & 13.5 & 12.2 & 601,920 & $5.84 \mathrm{E}-13$ & $6.96 \mathrm{E}-10$ \\
\hline 02. Gulf of Alaska & 11.1 & 242 & $2.70 \mathrm{E}+03$ & $1.35 \mathrm{E}+03$ & 17.4 & 2.40 & 329,528 & $6.17 \mathrm{E}-13$ & $8.32 \mathrm{E}-10$ \\
\hline 03. California Current & 6.09 & 278 & $1.69 \mathrm{E}+03$ & $8.46 \mathrm{E}+02$ & 10.2 & 0.470 & 112,754 & $2.32 \mathrm{E}-13$ & $1.97 \mathrm{E}-10$ \\
\hline 04. Gulf of California & 7.97 & 242 & $1.93 \mathrm{E}+03$ & $9.63 \mathrm{E}+02$ & 47.0 & 11.7 & 75,484 & $1.25 \mathrm{E}-11$ & $1.21 \mathrm{E}-08$ \\
\hline 05. Gulf of Mexico & 4.49 & 306 & $1.37 \mathrm{E}+03$ & $6.85 \mathrm{E}+02$ & 49.4 & 5.59 & 567,620 & $1.66 \mathrm{E}-12$ & $1.14 \mathrm{E}-09$ \\
\hline 06. Southeast U.S. Continental Shelf & 5.26 & 306 & $1.61 \mathrm{E}+03$ & $8.03 \mathrm{E}+02$ & 75.0 & 14.6 & 131,057 & $1.37 \mathrm{E}-11$ & $1.10 \mathrm{E}-08$ \\
\hline 07. Northeast U.S. Continental Shelf & 12.2 & 278 & $3.40 \mathrm{E}+03$ & $1.70 \mathrm{E}+03$ & 89.3 & 25.5 & 279,681 & $1.60 \mathrm{E}-11$ & $2.72 \mathrm{E}-08$ \\
\hline 08. Scotian Shelf & 11.6 & 242 & $2.80 \mathrm{E}+03$ & $1.40 \mathrm{E}+03$ & 66.1 & 17.1 & 224,439 & $9.17 \mathrm{E}-12$ & $1.28 \mathrm{E}-08$ \\
\hline 09. Newfoundland-Labrador Shelf & 10.3 & 242 & $2.49 \mathrm{E}+03$ & $1.24 \mathrm{E}+03$ & 49.5 & 17.8 & 486,595 & $3.84 \mathrm{E}-12$ & 4.77E-09 \\
\hline 10. Insular Pacific-Hawaiian & 1.33 & 306 & $4.05 \mathrm{E}+02$ & $2.03 \mathrm{E}+02$ & 12.0 & 0.000 & 20,432 & $6.19 \mathrm{E}-13$ & $1.25 \mathrm{E}-10$ \\
\hline 11. Pacific Central-American & 3.33 & 306 & $1.02 \mathrm{E}+03$ & $5.09 \mathrm{E}+02$ & 14.8 & 1.00 & 208,530 & $3.80 \mathrm{E}-13$ & $1.94 \mathrm{E}-10$ \\
\hline 12. Caribbean Sea & 2.51 & 306 & $7.67 \mathrm{E}+02$ & $3.83 \mathrm{E}+02$ & 34.0 & 1.85 & 518,460 & $5.39 \mathrm{E}-13$ & $2.07 \mathrm{E}-10$ \\
\hline 13. Humboldt Current & 8.38 & 278 & $2.33 \mathrm{E}+03$ & $1.17 \mathrm{E}+03$ & 9.65 & 0.983 & 302,712 & $1.95 \mathrm{E}-13$ & $2.28 \mathrm{E}-10$ \\
\hline 14. Patagonian Shelf & 11.5 & 242 & $2.78 \mathrm{E}+03$ & $1.39 \mathrm{E}+03$ & 37.5 & 2.92 & $1,004,605$ & $1.66 \mathrm{E}-12$ & 2.31E-09 \\
\hline 15. South Brazil Shelf & 5.84 & 242 & $1.41 \mathrm{E}+03$ & $7.06 \mathrm{E}+02$ & 56.9 & 6.51 & 282,944 & $5.20 \mathrm{E}-12$ & 3.67E-09 \\
\hline 16. East Brazil Shelf & 1.94 & 306 & $5.94 \mathrm{E}+02$ & $2.97 \mathrm{E}+02$ & 22.8 & 1.04 & 168,245 & $1.10 \mathrm{E}-12$ & $3.25 \mathrm{E}-10$ \\
\hline 17. North Brazil Shelf & 5.26 & 306 & $1.61 \mathrm{E}+03$ & $8.04 \mathrm{E}+02$ & 46.5 & 4.73 & 466,907 & $2.34 \mathrm{E}-12$ & $1.88 \mathrm{E}-09$ \\
\hline 18. Canadian Eastern Arctic - West Greenland & 6.80 & 218 & $1.48 \mathrm{E}+03$ & $7.42 \mathrm{E}+02$ & 9.60 & 3.63 & 398,787 & $1.52 \mathrm{E}-12$ & $1.13 \mathrm{E}-09$ \\
\hline 19. Greenland Sea & 7.25 & 218 & $1.58 \mathrm{E}+03$ & $7.91 \mathrm{E}+02$ & 6.72 & 4.45 & 90,224 & $6.73 \mathrm{E}-13$ & $5.32 \mathrm{E}-10$ \\
\hline
\end{tabular}




\begin{tabular}{|c|c|c|c|c|c|c|c|c|c|}
\hline 20. Barents Sea & 7.05 & 242 & $1.71 \mathrm{E}+03$ & $8.53 \mathrm{E}+02$ & 11.4 & 3.25 & 919,627 & $3.26 \mathrm{E}-13$ & $2.78 \mathrm{E}-10$ \\
\hline 21. Norwegian Sea & 6.35 & 242 & $1.54 \mathrm{E}+03$ & $7.68 \mathrm{E}+02$ & 18.7 & 3.11 & 54,020 & $8.66 \mathrm{E}-13$ & $6.65 \mathrm{E}-10$ \\
\hline 22. North Sea & 9.11 & 242 & $2.20 \mathrm{E}+03$ & $1.10 \mathrm{E}+03$ & 87.8 & 8.37 & 591,135 & $6.70 \mathrm{E}-12$ & 7.38E-09 \\
\hline 23. Baltic Sea & 15.9 & 242 & $3.85 \mathrm{E}+03$ & $1.93 \mathrm{E}+03$ & 24.7 & 3.91 & 387,139 & $3.60 \mathrm{E}-12$ & $6.93 \mathrm{E}-09$ \\
\hline 24. Celtic-Biscay Shelf & 8.15 & 278 & $2.26 \mathrm{E}+03$ & $1.13 \mathrm{E}+03$ & 95.9 & 14.1 & 528,284 & $6.71 \mathrm{E}-12$ & $7.60 \mathrm{E}-09$ \\
\hline 25. Iberian Coastal & 7.38 & 278 & $2.05 \mathrm{E}+03$ & $1.03 \mathrm{E}+03$ & 56.9 & 6.78 & 55,069 & $1.01 \mathrm{E}-11$ & $1.04 \mathrm{E}-08$ \\
\hline 26. Mediterranean & 3.45 & 278 & $9.60 \mathrm{E}+02$ & $4.80 \mathrm{E}+02$ & 55.1 & 7.27 & 530,429 & $1.17 \mathrm{E}-12$ & $5.60 \mathrm{E}-10$ \\
\hline 27. Canary Current & 7.73 & 242 & $1.87 \mathrm{E}+03$ & $9.34 \mathrm{E}+02$ & 42.9 & 3.44 & 195,439 & $1.97 \mathrm{E}-12$ & $1.84 \mathrm{E}-09$ \\
\hline 28. Guinea Current & 4.31 & 242 & $1.04 \mathrm{E}+03$ & $5.21 \mathrm{E}+02$ & 25.2 & 1.95 & 287,606 & $6.64 \mathrm{E}-13$ & $3.46 \mathrm{E}-10$ \\
\hline 29. Benguela Current & 9.09 & 242 & $2.20 \mathrm{E}+03$ & $1.10 \mathrm{E}+03$ & 32.3 & 2.21 & 199,456 & $1.11 \mathrm{E}-12$ & $1.22 \mathrm{E}-09$ \\
\hline 30. Agulhas Current & 4.76 & 306 & $1.46 \mathrm{E}+03$ & $7.28 \mathrm{E}+02$ & 22.6 & 2.46 & 316,710 & 4.43E-13 & $3.22 \mathrm{E}-10$ \\
\hline 31. Somali Coastal Current & 3.36 & 306 & $1.03 \mathrm{E}+03$ & $5.13 \mathrm{E}+02$ & 21.0 & 1.51 & 61,885 & $1.28 \mathrm{E}-12$ & $6.59 \mathrm{E}-10$ \\
\hline 32. Arabian Sea & 4.99 & 306 & $1.53 \mathrm{E}+03$ & $7.63 \mathrm{E}+02$ & 25.2 & 1.59 & 686,547 & $3.28 \mathrm{E}-13$ & $2.50 \mathrm{E}-10$ \\
\hline 33. Red Sea & 3.89 & 306 & $1.19 \mathrm{E}+03$ & $5.94 \mathrm{E}+02$ & 48.5 & 11.0 & 198,827 & $5.92 \mathrm{E}-12$ & $3.52 \mathrm{E}-09$ \\
\hline 34. Bay of Bengal & 3.71 & 306 & $1.13 \mathrm{E}+03$ & $5.67 \mathrm{E}+02$ & 28.0 & 2.01 & 657,300 & $3.90 \mathrm{E}-13$ & $2.21 \mathrm{E}-10$ \\
\hline 35. Gulf of Thailand & 4.17 & 306 & $1.27 \mathrm{E}+03$ & $6.37 \mathrm{E}+02$ & 77.8 & 11.5 & 385,957 & $1.07 \mathrm{E}-11$ & $6.84 \mathrm{E}-09$ \\
\hline 36. South China Sea & 2.70 & 306 & $8.26 \mathrm{E}+02$ & 4.13E+02 & 58.6 & 4.82 & $1,884,304$ & $9.46 \mathrm{E}-13$ & $3.90 \mathrm{E}-10$ \\
\hline 37. Sulu-Celebes Sea & 3.18 & 306 & $9.72 \mathrm{E}+02$ & $4.86 \mathrm{E}+02$ & 37.5 & 6.60 & 224,667 & $1.99 \mathrm{E}-12$ & $9.69 \mathrm{E}-10$ \\
\hline 38. Indonesian Sea & 3.69 & 306 & $1.13 \mathrm{E}+03$ & $5.64 \mathrm{E}+02$ & 48.8 & 5.85 & 829,346 & $1.15 \mathrm{E}-12$ & $6.46 \mathrm{E}-10$ \\
\hline 39. North Australian Shelf & 4.26 & 306 & $1.30 \mathrm{E}+03$ & $6.51 \mathrm{E}+02$ & 84.3 & 8.77 & 778,294 & $5.73 \mathrm{E}-12$ & 3.73E-09 \\
\hline 40. Northeast Australian Shelf & 1.93 & 306 & $5.90 \mathrm{E}+02$ & $2.95 \mathrm{E}+02$ & 37.1 & 2.45 & 303,792 & $1.47 \mathrm{E}-12$ & $4.33 \mathrm{E}-10$ \\
\hline 41. East-Central Australian Shelf & 3.51 & 242 & $8.48 \mathrm{E}+02$ & $4.24 \mathrm{E}+02$ & 18.1 & 0.949 & 67,670 & $1.40 \mathrm{E}-12$ & $5.92 \mathrm{E}-10$ \\
\hline 42. Southeast Australian Shelf & 5.41 & 278 & $1.51 \mathrm{E}+03$ & $7.53 \mathrm{E}+02$ & 17.3 & 0.615 & 219,772 & 7.33E-13 & $5.52 \mathrm{E}-10$ \\
\hline 43. Southwest Australian Shelf & 5.28 & 278 & $1.47 \mathrm{E}+03$ & $7.34 \mathrm{E}+02$ & 27.0 & 2.06 & 296,112 & $1.33 \mathrm{E}-12$ & $9.75 \mathrm{E}-10$ \\
\hline 44. West-Central Australian Shelf & 3.85 & 242 & $9.30 \mathrm{E}+02$ & $4.65 \mathrm{E}+02$ & 28.8 & 0.380 & 110,129 & $2.66 \mathrm{E}-12$ & $1.24 \mathrm{E}-09$ \\
\hline 45. Northwest Australian Shelf & 2.66 & 306 & $8.13 \mathrm{E}+02$ & $4.07 \mathrm{E}+02$ & 53.1 & 5.12 & 366,857 & $2.99 \mathrm{E}-12$ & $1.22 \mathrm{E}-09$ \\
\hline 46. New Zealand Shelf & 5.69 & 278 & $1.58 \mathrm{E}+03$ & $7.91 \mathrm{E}+02$ & 46.7 & 3.71 & 224,510 & $2.48 \mathrm{E}-12$ & $1.96 \mathrm{E}-09$ \\
\hline 47. East China Sea & 6.45 & 306 & $1.97 \mathrm{E}+03$ & $9.85 \mathrm{E}+02$ & 83.4 & 14.0 & 567,923 & $5.60 \mathrm{E}-12$ & $5.52 \mathrm{E}-09$ \\
\hline 48. Yellow Sea & 12.0 & 278 & $3.34 \mathrm{E}+03$ & $1.67 \mathrm{E}+03$ & 56.4 & 6.93 & 434,234 & $6.88 \mathrm{E}-12$ & $1.15 \mathrm{E}-08$ \\
\hline 49. Kuroshio Current & 3.37 & 242 & $8.16 \mathrm{E}+02$ & $4.08 \mathrm{E}+02$ & 22.4 & 2.10 & 102,224 & $8.63 \mathrm{E}-13$ & $3.52 \mathrm{E}-10$ \\
\hline 50. Sea of Japan/East Sea & 5.92 & 278 & $1.65 \mathrm{E}+03$ & $8.24 \mathrm{E}+02$ & 26.7 & 2.27 & 205,882 & $1.42 \mathrm{E}-12$ & $1.17 \mathrm{E}-09$ \\
\hline 51. Oyashio Current & 9.25 & 242 & $2.24 \mathrm{E}+03$ & $1.12 \mathrm{E}+03$ & 13.7 & 1.05 & 44,327 & $1.32 \mathrm{E}-12$ & $1.47 \mathrm{E}-09$ \\
\hline 52. Sea of Okhotsk & 10.0 & 242 & $2.42 \mathrm{E}+03$ & $1.21 \mathrm{E}+03$ & 21.1 & 1.62 & 600,353 & $7.04 \mathrm{E}-13$ & $8.52 \mathrm{E}-10$ \\
\hline 53. West Bering Sea & 7.80 & 242 & $1.89 \mathrm{E}+03$ & $9.43 \mathrm{E}+02$ & 1.20 & 0.144 & 113,202 & $2.80 \mathrm{E}-14$ & 2.64E-11 \\
\hline 54. Northern Bering - Chukchi Seas & 4.57 & 218 & $9.97 \mathrm{E}+02$ & $4.99 \mathrm{E}+02$ & 7.10 & 6.55 & 994,363 & $4.72 \mathrm{E}-13$ & $2.35 \mathrm{E}-10$ \\
\hline 55. Beaufort Sea & 5.87 & 218 & $1.28 \mathrm{E}+03$ & $6.41 \mathrm{E}+02$ & 3.43 & 2.05 & 401,019 & $2.76 \mathrm{E}-13$ & $1.77 \mathrm{E}-10$ \\
\hline 56. East Siberian Sea & 2.81 & 218 & $6.12 \mathrm{E}+02$ & $3.06 \mathrm{E}+02$ & 4.05 & 0.586 & 518,845 & $2.07 \mathrm{E}-13$ & $6.34 \mathrm{E}-11$ \\
\hline 57. Laptev Sea & 7.54 & 218 & $1.65 \mathrm{E}+03$ & $8.23 \mathrm{E}+02$ & 5.13 & 1.44 & 783,341 & $5.17 \mathrm{E}-13$ & $4.25 \mathrm{E}-10$ \\
\hline 58. Kara Sea & 6.22 & 218 & $1.36 \mathrm{E}+03$ & $6.78 \mathrm{E}+02$ & 5.02 & 1.35 & 802,720 & $2.83 \mathrm{E}-13$ & $1.92 \mathrm{E}-10$ \\
\hline 59. Iceland Shelf and Sea & 7.34 & 242 & $1.78 \mathrm{E}+03$ & $8.88 \mathrm{E}+02$ & 22.8 & 6.44 & 113,019 & $1.04 \mathrm{E}-12$ & $9.24 \mathrm{E}-10$ \\
\hline 60. Faroe Plateau & 5.58 & 242 & $1.35 \mathrm{E}+03$ & $6.74 \mathrm{E}+02$ & 51.0 & 27.2 & 27,119 & $1.70 \mathrm{E}-11$ & $1.15 \mathrm{E}-08$ \\
\hline 61. Antarctic & 4.91 & 218 & $1.07 \mathrm{E}+03$ & $5.35 \mathrm{E}+02$ & 3.36 & 0.003 & 491,798 & 4.24E-14 & 2.27E-11 \\
\hline 62. Black Sea & 8.83 & 278 & $2.45 \mathrm{E}+03$ & $1.23 \mathrm{E}+03$ & 21.8 & 3.41 & 150,185 & $2.59 \mathrm{E}-12$ & $3.18 \mathrm{E}-09$ \\
\hline 63. Hudson Bay Complex & 6.96 & 218 & $1.52 \mathrm{E}+03$ & $7.60 \mathrm{E}+02$ & 9.46 & 0.885 & $1,099,739$ & $4.17 \mathrm{E}-13$ & 3.17E-10 \\
\hline 64. Central Arctic Ocean & 0.450 & 218 & $9.82 \mathrm{E}+01$ & $4.91 \mathrm{E}+01$ & 1.25 & 0.512 & 1,535 & $1.79 \mathrm{E}-14$ & $8.81 \mathrm{E}-13$ \\
\hline 65. Aleutian Islands & 9.96 & 242 & $2.41 \mathrm{E}+03$ & $1.20 \mathrm{E}+03$ & 9.79 & 11.7 & 37,737 & $4.98 \mathrm{E}-13$ & $6.00 \mathrm{E}-10$ \\
\hline 66. Canadian High Arctic - North Greenland & 2.99 & 218 & $6.53 \mathrm{E}+02$ & $3.27 \mathrm{E}+02$ & 5.21 & 1.85 & 172,572 & $3.77 \mathrm{E}-13$ & $1.23 \mathrm{E}-10$ \\
\hline Maximum $=$ & 15.9 & 306 & $3.85 \mathrm{E}+03$ & $1.93 \mathrm{E}+03$ & 95.9 & -- & -- & $1.70 \mathrm{E}-11$ & 2.72E-08 \\
\hline Minimum $=$ & 0.450 & 218 & $9.82 \mathrm{E}+01$ & $4.91 \mathrm{E}+01$ & 1.25 & -- & -- & $1.79 \mathrm{E}-14$ & $8.81 \mathrm{E}-13$ \\
\hline
\end{tabular}

\subsection{Spatially explicit damage scores}

Species densities (SDs, Figure 2) were derived from species richness (SR, Figure S.5) and benthicdemersal habitat volumes per LME (Table 1). SD values vary from $1.8 \times 10^{-14}$ species $\cdot \mathrm{m}^{-3}$ (in LME\#64 Central Arctic Ocean) to $1.7 \times 10^{-11}$ species $\mathrm{m}^{-3}$ (in LME\#60 Faroe Plateau) - i.e. 3 orders of magnitude of spatial differentiation.

The calculated marine eutrophication Ecosystem Damage (meED) indicators are also compiled in Table 1 and their distribution shown in Figure 3. Results for $m e E D$ vary from $8.8 \times 10^{-13}$ species $\cdot \mathrm{kgN}^{-1}$ (in LME\#64 Central Arctic Ocean) to $2.7 \times 10^{-8}$ species $\cdot \mathrm{kgN}^{-1}$ (in LME\#7 Northeast U.S. Continental Shelf) - i.e. more than 4 orders of magnitude of spatial differentiation. The distribution pattern of the SDs (Figure 2) is determinant for the meED scores distribution, showing the same high-scoring LMEs, which is explained by the lower variation range of the ER scores (factor ca. 39) when compared to the SD variation (factor ca. 948). As the meED is merely an indicator of a potential impact in the receiving LME these results show the relevance of managing anthropogenic emissions to these water masses, possibly at a river basin scale. It also points out the need to further include environmental fate modelling to ensure completeness of the impact 
pathway and link (human-driven) causes to (environmental) effects through the ecosystem response dimension.

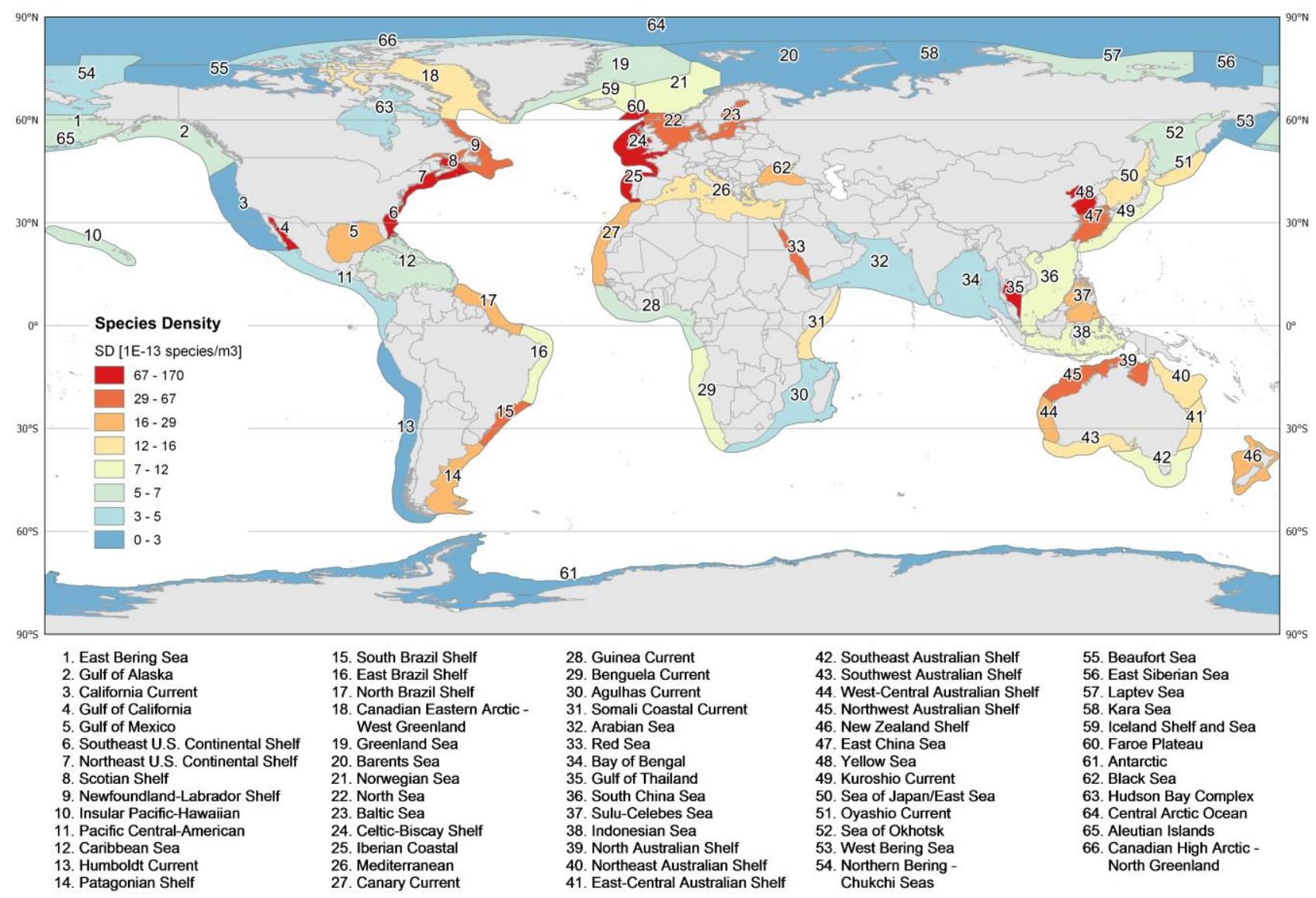

Figure 2 Distribution of species density (SD) values estimated from a set of 626 exploited demersal (benthic and benthopelagic) fish and invertebrates species, per Large Marine Ecosystem (LME). Note the non-linear scale. Figure available online in colour. 


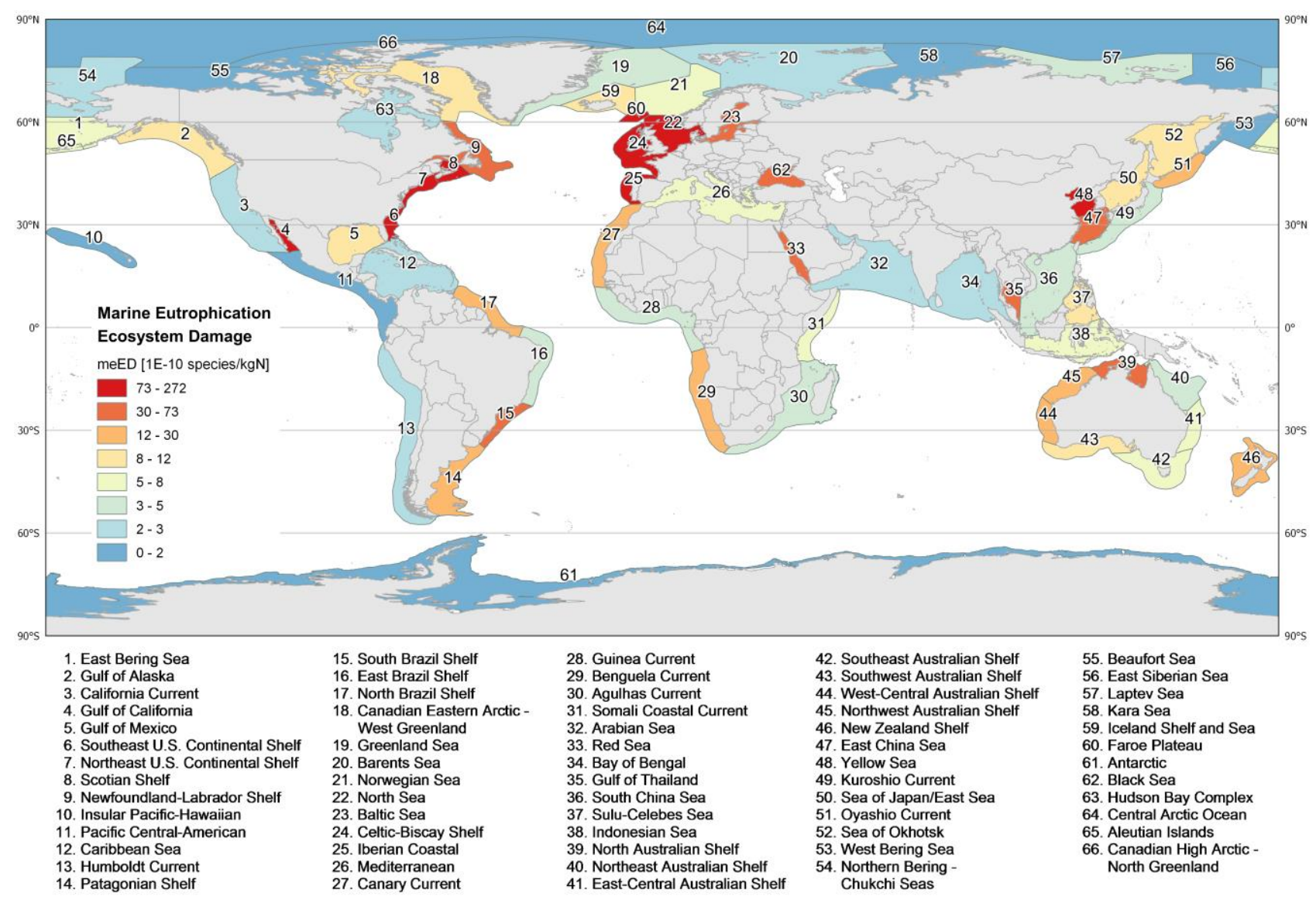

Figure 3 Global distribution of the marine eutrophication Ecosystem Damage scores $\left(m e E D\right.$, [species $\left.\left.\cdot \mathrm{kgN}^{-1}\right]\right)$ per Large Marine Ecosystem (LME). Note the non-linear scale. Figure available online in colour.

\subsection{PAF to PDF - the relative metrics}

The majority of ecosystem-damage indicators report the environmental disturbance as a loss of species richness for its modelling feasibility and data availability. International databases of species distributions, e.g. Ocean Biogeographic Information System (OBIS, www.iobis.org), FishBase (www.fishbase.org), SeaLifeBase (www.sealifebase.org), World Register of Marine Species (WoRMS, www.marinespecies.org), may provide modellers with spatially explicit data relevant for e.g. ecotoxicity, ocean acidification, and marine eutrophication (Cosme and Hauschild, 2016). On a methodological perspective, different taxonomic groups (e.g. marine invertebrates, terrestrial mammals) and biological endpoints (e.g. ventilation rate, death) are widely used to estimate average or marginal responses in species richness, thus adding harmonisation issues as questions arise: is the species richness dimension of the impacts built on species-area relationships equivalent to that of SSD-based indicators? And within these, does NOEC-, LOEC-, $\mathrm{EC}_{50^{-}}, \mathrm{LC}_{50}$-based sensitivity indicators contribute equally to an AoP-aggregated damage dimension? And should PAF to PDF conversions be spatially differentiated too or is a global generic relationship conceptually acceptable?

Implicitly in this method, the derived LOEC values tend to define a PAF-like metric, which does not necessarily lead to a non-occurrence of species characteristic of PDF. Persistent or recurrent sublethal stress in PAF-like environmental conditions, i.e. in which species are affected but still occur, may however bring costly metabolic, physiological, or reproductive consequences for the exposed species, and avoidance behaviour (a disappearance nonetheless). In the long run, these would qualify as an impact beyond what PAF 
is able to express, due to the incompatibility given by time integration in LCIA modelling, and be closer to represent a true PDF. At the other end, brief PAF-like exposure events may easily be compensated by physiological or ecological feedbacks and have no long-term impacts.

Assuming a continuum between what PAF- and PDF-based indicators mean, a metrics conversion may find ground for application. Approaches to quantify a PAF-to-PDF conversion and derive a damage factor are briefly discussed elsewhere (Jolliet et al., 2003; Larsen and Hauschild, 2007). Based on a time-integrated modelling approach, the exposure to environmental conditions between sublethal and lethal levels, the seasonality of the stressor, and for moderate intensity and duration between the PAF and PDF extremes (as mentioned earlier), the assumption that one half of the species affected (as PAF) would tend to not occur (and be expressed as PDF), i.e. a conversion factor of 0.5 (see Eq. 4), was chosen.

For ecosystem-related LCIA indicators, the probability of non-occurrence of species is modelled with a 'media recovery' assumption, i.e. species reappear when the stressor intensity falls below a sensitivity threshold, assuming a reversible cause-effect link (Larsen and Hauschild, 2007). Such assumption verifies when vulnerability and recoverability are weighted equally across species and no cumulative effects based on stressor persistence are modelled. In any case, modelling species' or communities' differentiated capacity to recover shows high environmental relevance. In this line, adding vulnerability indices to richness assessments (e.g. Curran et al., 2011; Verones et al., 2015, 2013), or Mean Extinction Time as discussed in Larsen and Hauschild (2007), along with spatial differentiation as shown here, may represent valuable methodological improvements. Similarly, 'media recovery' does not verify also if endemism is involved meaning that the extirpation of exposed endemic species necessarily leads to their disappearance and so failing the otherwise assumed reappearance. Future generations of ecosystem-damage assessment methods may add to the multitude of factors built on biological attributes, for which structure and function are still missing to a large extent (Curran et al., 2011; Souza et al., 2013), and others on the disturbance on delivering ecological services (Othoniel et al., 2016; Y. Zhang et al., 2010). However, ecosystem services as a metric can only succeed when spatially explicit valuations are produced and databases made available.

The occurrence of eutrophication impacts is correlated with the seasonality of e.g. nutrients emission flows, biological response, water temperature, stratification, and hypoxia (Behrenfeld and Boss, 2014; Cushing, 1959; Diaz, 2001; Justić et al., 1993; Lutz et al., 2007; Michael Beman et al., 2005; Rabalais, 2002; Rabalais et al., 2010; Rosenberg, 1985; Smith et al., 1992). Emissions are not evenly distributed over the year, planktonic productivity varies with latitude and season, and so do the conditions for the onset of stratification and hypoxia. These may suggest a useful inclusion of temporal modelling of effects, considering that stressors' timing, duration, intensity, and recurrence are factors contributing to species disappearance (Pickett and White, 1985) that reduce the habitat suitability or hinder reproductive success, i.e. pushing PAF closer to PDF.

\subsection{Harmonization of damage indicators - the absolute metrics}

The terms endpoint and damage are usually applied interchangeably in LCIA. However, a distinction is made here for clarity reasons - endpoint refers to the relative metric (PAF- or PDF-integrated) whereas damage is used to refer to the absolute metric (species-integrated). The indicators at both level can be useful for coastal, ecological, or water quality management. However, an endpoint unit is less transparent and informative to managers and decision makers (or to other non-technical audiences) for 3 reasons: (1) it misses the differentiated potential impacts to individual LMEs, when local or regional impacts are to be modelled, as only spatially explicit SDs can discriminate the number of species exposed - the EF is focused on (available) species composition data and sensitivity, suggesting that each LME is quantitatively and 
qualitatively distinct - still, an increase of spatial resolution of the EF model work can be seen as a method improvement here; (2) the decoupling of the indicator from the community makes PAF- and PDF-integrated units (fractions) less communicable, in opposition to an easier to grasp absolute number of species in the damage unit; and (3) it misses the ability to match the dimension of other indicators and the aggregation into a common damage category.

Endpoint indicators for ecosystem impacts are a quantifiable representation of the changes in the quality status, or damages, in this entity (Jolliet et al., 2004). Marine eutrophication typically falls in this classification and its indicator assigned to the AoP Ecosystems. Various other indicators also contribute to the same AoP, e.g. terrestrial ecotoxicity, freshwater eutrophication, marine acidification. Such indicators are ideally expressed in a common unit to facilitate their comparison and aggregation, if desired. However, available endpoint-oriented and combined midpoint-endpoint LCIA methods differ in the units representing such damage to ecosystem - one can find e.g. $(\mathrm{PDF}) \cdot \mathrm{m}^{2}{ }^{\text {or } 3} \cdot \mathrm{yr}$ (respectively for area or volume and time integrated PDF), Expected Increase in Number of Extinct Species (EINES) (Itsubo and Inaba, 2012), or normalized extinction of species (NEX, dimensionless) (Steen, 1999). More importantly, the PDF-integrated units do not necessarily refer to a comparable biotic component of the ecosystem, thus failing to express a joint measure of biodiversity change. Taking the mentioned impact categories, terrestrial ecotoxicity necessarily affects land-based species that may not coincide with freshwater systems species (and covered by eutrophication impact models there), which in turn differ from marine species (used to model ocean acidification impacts) - despite all three indicators are expressed in PDF-integrated units. Finally, within non-global impact indicators, such as eutrophication, the naturally occurring variability of species in distinct geographic locations is not entirely accounted for in current LCIA methods at the damage level. The absolute number of species in a certain area, that a relative PDF-integrated unit represents (a fraction all the same), may not necessarily match the same amount of species elsewhere for the same quantified anthropogenic pressure. Harmonisation of the ecological meaning of PDF-integrated units by means of spatial differentiation in both impacts modelling (endpoint level) and SD (damage level) seems essential to deliver a common and truly comparable species.yr unit. In that line, aggregation of damage-like units is justifiable. On the downside, further uncertainty is added by the extra modelling of SD applied in the damage indicator. However, the trade-off between the environmental relevance given by the spatial differentiation and the added uncertainty seems to favour the former when addressing local to regional impacts, such as hypoxiadriven marine eutrophication. The loss of information on specific indicators after damage aggregation is an unavoidable feature of the LCA methodology itself and not really a caveat of the specific impact indicator modelling.

\subsection{Spatial resolution and LME biogeographical classification system}

Considering the scale at which the marine eutrophication impacts and relevant species occur, the adopted LME biogeographical classification system seems adequate. Alternatively, any other coastal spatial zonation can be used, as long as the necessary data for the exposure/effect models and species density are available at such resolution, e.g. PP rates (for XF), benthic water temperature (for EF), species occurrence (for $\mathrm{EF}$ and $\mathrm{SD}$ ), and area (for SD).

\subsection{Species density estimation methods}

Species density estimates are largely based on the predicted occurrence from SDMs, and thus will be affected by the uncertainties of the predictions. Here, the multiple model ensemble approach used increases the robustness of the predictions, as also noted by Araújo and New (2007). Previous assessment on the skills of the three SDMs employed demonstrated the difficulty of identifying a single optimal model; instead, the 
multi-model approach was preferred (Jones et al., 2012). However, the predicted species occurrence may still be affected by a number of uncertainties inherent of SDMs. Firstly, the SDMs assume that species' distribution was in equilibrium with the environmental conditions in the last few decades, which may not be valid particularly under climate change (Pörtner et al., 2014). Secondly, the SDMs do not explicitly account for biotic interactions. Also, the predicted SDs may be biased by the sample of modelled species. Species were included in the study when they were reported in the fisheries catch statistics. Thus, area may be underor over-represented because of differences in taxonomic resolution of their catch statistics. For example, the high SD in Northeast and Northwest Atlantic is partly because of the high taxonomic resolution of catch statistics of countries in these regions. Acknowledging possible species representativeness concerns due to data availability, the use of the present dataset is considered a best estimate.

\subsection{Implications for LCIA modelling}

The characterisation of environmental emissions from anthropogenic sources is at the core of LCA methodologies. The inclusion of spatial differentiation in marine eutrophication damage modelling seems a valuable contribution to the LCIA phase of life cycle assessment as an improvement to current, site-generic, methodologies. Complementing the fate modelling of waterborne emissions with deposition of airborne Nforms to soils, fresh- and marine waters, is essential to compose meaningful CFs. This is clearly a methodological need and further work is recommended to close this gap. The present work introduces methodology developments in spatial differentiation on both the impact assessment and the damage assessment, which is an important feature considering the local to regional character of marine eutrophication impacts.

The application of this approach to characterise the response to N-enrichment can be extended to Penrichment, if relevant, e.g. for P-limited marine waters. In such cases, a simple Redfield ratio-based stoichiometric conversion of the XF indicator would be required, since the remaining of the impact pathway is independent of the nutrient.

\section{Conclusions}

This study describes the damage potential of nitrogen uptake by phytoplankton in a cascade of effects typical of marine eutrophication. Relevant applications of the damage indicator, obtained with the proposed methodology, include impacts assessment and ecosystem management in areas affected by riverine discharge of $\mathrm{N}$ forms, particularly if the respective watershed has a significant contribution from agriculture runoff. An endpoint-to-damage conversion is discussed and applied to deliver spatially explicit damage scores of the ecosystem response to $\mathrm{N}$ inputs in a metric that is consistent and harmonised with other endpoint ecosystemrelated indicators in life cycle impact assessment.

A 4-order magnitude of spatial differentiation of the resulting LME-dependent indicators is not only justified by spatially distinct exposure and effect models, but also by the differentiation of the impacts significance to the ecological community at its occurrence location. The introduced method shows important and novel features when compared to available current methodologies. As such, the adaptation of the described marine eutrophication ecosystem damage ( $m e E D)$ indicator is suggested for LCIA application. Its adoption in characterisation modelling of anthropogenic-N emissions in a life cycle perspective may contribute with essential components to an already proven tool for sustainability assessment of human activities. 


\section{References}

Araújo, M.B., New, M., 2007. Ensemble forecasting of species distributions. Trends Ecol. Evol. 22, 42-47. doi:10.1016/j.tree.2006.09.010

Arrigo, K.R., 2005. Marine microorganisms and global nutrient cycles. Nature 437, 349-356. doi:10.1038/nature04159

Behrenfeld, M.J., Boss, E.S., 2014. Resurrecting the ecological underpinnings of ocean plankton blooms. Ann. Rev. Mar. Sci. 6, 167-94. doi:10.1146/annurev-marine-052913-021325

Chavez, F.P., Messié, M., Pennington, J.T., 2011. Marine Primary Production in Relation to Climate Variability and Change. Ann. Rev. Mar. Sci. 3, 227-260. doi:10.1146/annurev.marine.010908.163917

Cheung, W.W.L., Lam, V.W.Y., Pauly, D., 2008. Modelling Present and Climate - Fishes and Invertebrates. Fish. Cent. Res. Reports 16, 72.

Close, C., Cheung, W.W.L., Hodgson, S., Lam, V.W.Y., Watson, R., Pauly, D., 2006. Distribution ranges of commercial fishes and invertebrates, in: Palomares, M.L., Stergiou, K.I., Pauly, D. (Eds.), Fishes in Databases and Ecosystems. Fisheries Centre Research Reports 14(4). Vancouver, pp. 27-37.

Cosme, N., Hauschild, M.Z., 2016. Effect factors for marine eutrophication in LCIA based on species sensitivity to hypoxia. Ecol. Indic. 69, 453-462. doi:10.1016/j.ecolind.2016.04.006

Cosme, N., Koski, M., Hauschild, M.Z., 2015. Exposure factors for marine eutrophication impacts assessment based on a mechanistic biological model. Ecol. Modell. 317, 50-63. doi:10.1016/j.ecolmodel.2015.09.005

Cosme, N., Mayorga, E., Hauschild, M.Z., 2016. Spatially explicit fate factors for waterborne nitrogen emissions at the global scale. Int. J. Life Cycle Assess. submitted.

Curran, M., de Baan, L., De Schryver, A.M., Van Zelm, R., Hellweg, S., Koellner, T., Sonnemann, G., Huijbregts, M.A.J., 2011. Toward meaningful end points of biodiversity in life cycle assessment. Environ. Sci. Technol. 45, 70-9. doi:10.1021/es101444k

Cushing, D.H., 1959. The seasonal variation in oceanic production as a problem in population dynamics. J. Cons. int. Explor. Mer 24, 455-464. doi:doi:10.1093/icesjms/24.3.455

Davis, J.C., 1975. Minimal dissolved oxygen requirements of aquatic life with emphasis on Canadian species: a review. J. Fish. Res. Board Canada 32, 2295-2332.

Dentener, F.J., Drevet, J., Lamarque, J.F., Bey, I., Eickhout, B., Fiore, A.M., Hauglustaine, D., Horowitz, L.W., Krol, M., Kulshrestha, U.C., Lawrence, M., Galy-Lacaux, C., Rast, S., Shindell, D., Stevenson, D., Van Noije, T., Atherton, C., Bell, N., Bergman, D., Butler, T., Cofala, J., Collins, B., Doherty, R., Ellingsen, K., Galloway, J.N., Gauss, M., Montanaro, V., Müller, J.F., Pitari, G., Rodriguez, J., Sanderson, M., Solmon, F., Strahan, S., Schultz, M., Sudo, K., Szopa, S., Wild, O., 2006. Nitrogen and sulfur deposition on regional and global scales: A multimodel evaluation. Global Biogeochem. Cycles 20, 1-21. doi:10.1029/2005GB002672

Diaz, R.J., 2001. Overview of Hypoxia around the World. J. Environ. Qual. 30, $275-81$.

Diaz, R.J., Rosenberg, R., 2008. Spreading dead zones and consequences for marine ecosystems. Science (80-. ). 321, 926-929. doi:10.1126/science.1156401

Diaz, R.J., Rosenberg, R., 1995. Marine Benthic Hypoxia: a Review of Its Ecological Effects and the Behavioural Responses of Benthic Macrofauna, in: Ansell, A.D., Gibson, R.N., Barnes, M. (Eds.), 
Oceanography and Marine Biology: An Annual Review. UCL Press, pp. 245-303.

Doray, M., Trenkel, V.M., 2010. Estimating gear efficiency in a combined acoustic and trawl survey, with reference to the spatial distribution of demersal fish. ICES J. Mar. Sci. 67, 668-676. doi:dx.doi.org/10.1093/icesjms/fsp277

EC-JRC, 2010. ILCD Handbook: Analysis of existing Environmental Impact Assessment methodologies for use in Life Cycle Assessment, 1st edit. ed. Publications Office of the European Union, Luxembourg.

Elser, J.J., Bracken, M.E.S., Cleland, E.E., Gruner, D.S., Harpole, W.S., Hillebrand, H., Ngai, J.T., Seabloom, E.W., Shurin, J.B., Smith, J.E., 2007. Global analysis of nitrogen and phosphorus limitation of primary producers in freshwater, marine and terrestrial ecosystems. Ecol. Lett. 10, 1135-42. doi:10.1111/j.1461-0248.2007.01113.x

Falkowski, P.G., Raven, J.A., 2007. Aquatic Photosynthesis, Second Edi. ed. Princeton University Press, Oxford, UK. doi:10.1017/CBO9781107415324.004

Galloway, J.N., Townsend, A.R., Erisman, J.W., Bekunda, M., Cai, Z., Freney, J.R., Martinelli, L.A., Seitzinger, S.P., Sutton, M.A., 2008. Transformation of the Nitrogen Cycle: Recent Trends, Questions, and Potential Solutions. Science (80-. ). 320, 889-892. doi:10.1126/science.1136674

GESAMP, 2001. A Sea of Troubles. Rep. Stud. GESAMP No. 70. Joint Group of Experts on the Scientific Aspects of Marine Environmental Protection and Advisory Committee on Protection of the Sea.

Goedkoop, M., Heijungs, R., Huijbregts, M.A.J., De Schryver, A.M., Struijs, J., van Zelm, R., 2012. ReCiPe 2008 - A life cycle impact assessment method which comprises harmonised category indicators at the midpoint and the endpoint level. First edition (revised) Report I: Characterisation; July 2012, http://www.lcia-recipe.net.

Goedkoop, M., Spriensma, R., 2000. The Eco-indicator 99 A damage oriented method for Life Cycle Impact Assessment Methodology Report.

Graf, G., Bengtsson, W., Diesner, U., Schulz, R., Theede, H., 1982. Benthic response to sedimentation of a spring phytoplankton bloom: Process and budget. Mar. Biol. 67, 201-208. doi:10.1007/BF00401286

Gray, J.S., Wu, R.S., Or, Y.Y., 2002. Effects of hypoxia and organic enrichment on the coastal marine environment. Mar. Ecol. Prog. Ser. 238, 249-279.

Guinée, J.B., Gorrée, M., Heijungs, R., Huppes, G., Kleijn, R., Koning, A. de, Oers, L. van, Sleeswijk, A.W., Suh, S., Udo de Haes, H.A., Bruijn, H. de, Duin, R. van, Huijbregts, M.A.J., 2002. Handbook on life cycle assessment. Operational guide to the ISO standards. I: LCA in perspective. IIa: Guide. IIb: Operational annex. III: Scientific background. Kluwer Academic Publishers, Dordrecht.

Hauschild, M.Z., 2005. Assessing Environmental Impacts in a Life-Cycle Perspective. Environ. Sci. Technol. 39, 81-88. doi:10.1021/es053190s

Hauschild, M.Z., Goedkoop, M., Guinée, J.B., Heijungs, R., Huijbregts, M.A.J., Jolliet, O., Margni, M., De Schryver, A.M., Humbert, S., Laurent, A., Sala, S., Pant, R., 2013. Identifying best existing practice for characterization modeling in life cycle impact assessment. Int. J. Life Cycle Assess. 18, 683-697. doi:10.1007/s11367-012-0489-5

Hauschild, M.Z., Potting, J., 2005. Spatial Differentiation in Life Cycle Impact Assessment - The EDIP2003 methodology, Environmental News No. 80.

Heijungs, R., 2005. On the use of units in LCA. Int. J. Life Cycle Assess. 10, 173-176. doi:http://dx.doi.org/10.1065/lca2005.02.199 
Henderson, A.D., 2015. Eutrophication, in: Hauschild, M.Z., Huijbregts, M.A.J. (Eds.), Life Cycle Impact Assessment, LCA Compendium - The Complete World of Life Cycle Assessment. Springer Science+Business Media Dordrecht, pp. 177-196. doi:10.1007/978-94-017-9744-3

Hjellvik, V., Michalsen, K., Aglen, A., Nakken, O., 2003. An attempt at estimating the effective fishing height of the bottom trawl using acoustic survey recordings. ICES J. Mar. Sci. 967-979. doi:10.1016/S1054-3139(03)00116-4

Howarth, R.W., Marino, R., 2006. Nitrogen as the limiting nutrient for eutrophication in coastal marine ecosystems: Evolving views over three decades. Limnol. Oceanogr. 51, 364-376. doi:10.4319/lo.2006.51.1_part_2.0364

Hutchinson, G.E., 1957. Concluding remarks. Cold Spring Harb. Symp. Quant. Biol. 22, 415-427.

Itsubo, N., Inaba, A., 2012. LIME2: Life-cycle Impact assessment Method based on Endpoint modeling. JLCA Newsl. Life-Cycle Assess. Soc. Japan 12, 16.

Jolliet, O., Margni, M., Charles, R., Humbert, S., Payet, J., Rebitzer, G., 2003. Presenting a New Method IMPACT 2002+: A New Life Cycle Impact Assessment Methodology. Int. J. Life Cycle Assess. 8, 324-330.

Jolliet, O., Müller-Wenk, R., Bare, J.C., Brent, A., Goedkoop, M., Heijungs, R., Itsubo, N., Peña, C., Pennington, D.W., Potting, J., Rebitzer, G., Stewart, M., Udo de Haes, H.A., Weidema, B.P., 2004. The LCIA Midpoint-damage Framework of the UNEP/SETAC Life Cycle Initiative. Int. J. Life Cycle Assess. 9, 394-404.

Jones, M.C., Cheung, W.W.L., 2015. Multi-model ensemble projections of climate change effects on global marine biodiversity. ICES J. Mar. Sci. 72, 741-752. doi:10.1093/icesjms/fsu172

Jones, M.C., Dye, S.R., Pinnegar, J.K., Warren, R., Cheung, W.W.L., 2012. Modelling commercial fish distributions: Prediction and assessment using different approaches. Ecol. Modell. 225, 133-145. doi:10.1016/j.ecolmodel.2011.11.003

Justić, D., Rabalais, N.N., Turner, R.E., Wiseman, W.J.J., 1993. Seasonal coupling between riverborne nutrients, net productivity and hypoxia. Mar. Pollut. Bull. 26, 184-189. doi:10.1016/0025326X(93)90620-Y

Larsen, H.F., Hauschild, M.Z., 2007. LCA Methodology Evaluation of Ecotoxicity Effect Indicators for Use in LCIA. Int. J. Life Cycle Assess. 12, 24-33.

Levin, L.A., Ekau, W., Gooday, A.J., Jorissen, F., Middelburg, J.J., Naqvi, S.W.A., Neira, C., Rabalais, N.N., Zhang, J., 2009. Effects of natural and human-induced hypoxia on coastal benthos. Biogeosciences 6, 2063-2098.

Lutz, M.J., Caldeira, K., Dunbar, R.B., Behrenfeld, M.J., 2007. Seasonal rhythms of net primary production and particulate organic carbon flux to depth describe the efficiency of biological pump in the global ocean. J. Geophys. Res. 112, C10011. doi:10.1029/2006JC003706

Michael Beman, J., Arrigo, K.R., Matson, P.A., 2005. Agricultural runoff fuels large phytoplankton blooms in vulnerable areas of the ocean. Nature 434, 211-214. doi:10.1038/nature03370

Middelburg, J.J., Levin, L.A., 2009. Coastal hypoxia and sediment biogeochemistry. Biogeosciences 6, 1273-1293. doi:10.5194/bg-6-1273-2009

Othoniel, B., Rugani, B., Heijungs, R., Benetto, E., Withagen, C.A.A.M., 2016. Assessment of life cycle impacts on ecosystem services: promise, problems and prospects. Environ. Sci. Technol. 
acs.est.5b03706. doi:10.1021/acs.est.5b03706

Pennington, D.W., Payet, J., Hauschild, M.Z., 2004a. Aquatic Ecotoxicological Indicators In Life-Cycle Assessment. Environ. Toxicol. Chem. 23, 1796-1807.

Pennington, D.W., Potting, J., Finnveden, G., Lindeijer, E., Jolliet, O., Rydberg, T., Rebitzer, G., 2004b. Life cycle assessment Part 2: Current impact assessment practice. Environ. Int. 30, 721-39. doi:10.1016/j.envint.2003.12.009

Pickett, S.T.A., White, P.S., 1985. Natural disturbance and patch dynamics: An introduction, The Ecology of Natural Disturbance and Patch Dynamics. Academic Press, San Diego. doi:10.2307/2403105

Ploug, H., Grossart, H.-P., Azam, Farooq, Jørgensen, B.B., 1999. Photosynthesis, respiration, and carbon turnover in sinking marine snow from surface waters of Southern California Bight: implications for the carbon cycle in the ocean. Mar. Ecol. Prog. Ser. 179, 1-11.

Pörtner, H.-O., Karl, D.M., Boyd, P.W., Cheung, W.W.L., Lluch-Cota, S.E., Nojiri, Y., Schmidt, D.N., Zavialov, P.O., 2014. Ocean systems, in: Field, C.B., Barros, V.R., Dokken, D.J., Mach, K.J., Mastrandrea, M.D., Bilir, T.E., Chatterjee, M., Ebi, K.L., Estrada, Y.O., Genova, R.C., Girma, B., Kissel, E.S., Levy, A.N., MacCracken, S., Mastrandrea, P.R., White, L.L. (Eds.), Climate Change 2014: Impacts, Adaptation, and Vulnerability. Part A: Global and Sectoral Aspects. Contribution of Working Group II to the Fifth Assessment Report of the Intergovernmental Panel on Climate Change. Cambridge University Press, Cambridge, United Kingdom and New York, NY, USA, pp. 411-484.

Posthuma, L., Suter II, G.W., Traas, T.P. (Eds.), 2002. Species Sensitivity Distributions in Ecotoxicology, Environmental and Ecological Risk Assessment. Lewis Publishers.

Rabalais, N.N., 2002. Nitrogen in Aquatic Ecosystems. Ambio 31, 102-112.

Rabalais, N.N., Diaz, R.J., Levin, L.A., Turner, R.E., Gilbert, D., Zhang, J., 2010. Dynamics and distribution of natural and human-caused coastal hypoxia. Biogeosciences 7, 585-619. doi:10.5194/bgd-6-93592009

Rabalais, N.N., Turner, R.E., Diaz, R.J., Justić, D., 2009. Global change and eutrophication of coastal waters. ICES J. Mar. Sci. 66, 1528-1537.

Rosenberg, R., 1985. Eutrophication - the future marine coastal nuisance? Mar. Pollut. Bull. 16, 227-231. doi:10.1016/0025-326X(85)90505-3

Roy, P.-O., Huijbregts, M.A.J., Deschênes, L., Margni, M., 2012. Spatially-differentiated atmospheric source-receptor relationships for nitrogen oxides, sulfur oxides and ammonia emissions at the global scale for life cycle impact assessment. Atmos. Environ. 62, 74-81. doi:10.1016/j.atmosenv.2012.07.069

Sherman, K., Alexander, L.M. (Eds.), 1986. Variability and Management of Large Marine Ecosystems. Westview Press Inc., Boulder, CO.

Smith, D.E., Leffler, M., Mackiernan, G., 1992. Oxygen dynamics in the Chesapeake Bay - A synthesis of recent research. University of Maryland, Maryland Sea Grant, Maryland, MD.

Smith, V.H., Tilman, G.D., Nekola, J.C., 1999. Eutrophication: impacts of excess nutrient inputs on freshwater, marine, and terrestrial ecosystems. Environ. Pollut. 100, 179-196.

Souza, D.M. de, Flynn, D.F.B., Declerck, F., Rosenbaum, R.K., De Melo Lisboa, H., Koellner, T., 2013. Land use impacts on biodiversity in LCA: Proposal of characterization factors based on functional diversity. Int. J. Life Cycle Assess. 18, 1231-1242. doi:10.1007/s11367-013-0578-0 
Steen, B., 1999. A systematic approach to environmental priority strategies in product development (EPS). Version 2000 - General system characteristics. CPM report 1999:4. Gothenburg, Sweden.

Turner, R.E., Qureshi, N., Rabalais, N.N., Dortch, Q., Justić, D., Shaw, R.F., Cope, J., 1998. Fluctuating silicate: nitrate ratios and coastal plankton food webs. Proc. Natl. Acad. Sci. U. S. A. 95, 13048-13051.

Udo de Haes, H.A., Finnveden, G., Goedkoop, M., Hauschild, M.Z., Hertwich, E., Hofstetter, P., Jolliet, O., Klöpffer, W., Krewitt, W., Lindeijer, E., Müller-Wenk, R., Olsen, S.I., Pennington, D.W., Potting, J., Steen, B., 2002. Life-Cycle Impact Assessment: Striving Towards Best Practice. SETAC Press, Pensacola, FL, USA.

Udo de Haes, H.A., Jolliet, O., Finnveden, G., Hauschild, M.Z., Krewitt, W., Müller-Wenk, R., 1999. Best Available Practice Regarding Impact Categories and Category Indicators in Life Cycle Impact Assessment. Int. J. Life Cycle Assess. 4, 66-74.

Vaquer-Sunyer, R., Duarte, C.M., 2008. Thresholds of hypoxia for marine biodiversity. Proc. Natl. Acad. Sci. U. S. A. 105, 15452-7. doi:10.1073/pnas.0803833105

Verones, F., Huijbregts, M.A.J., Chaudhary, A., de Baan, L., Koellner, T., Hellweg, S., 2015. Harmonizing the assessment of biodiversity effects from land and water use within LCA. Environ. Sci. Technol. 49, 3584-3592. doi:10.1021/es504995r

Verones, F., Saner, D., Pfister, S., Baisero, D., Rondinini, C., Hellweg, S., 2013. Effects of consumptive water use on biodiversity in wetlands of international importance. Environ. Sci. Technol. 47, 12248-57. doi:10.1021/es403635j

Vitousek, P.M., Hättenschwiler, S., Olander, L., Allison, S., 2002. Nitrogen and nature. Ambio 31, 97-101.

Wu, R.S., 2002. Hypoxia: from molecular responses to ecosystem responses. Mar. Pollut. Bull. 45, 35-45.

Zhang, J., Gilbert, D., Gooday, A.J., Levin, L.A., Naqvi, S.W.A., Middelburg, J.J., Scranton, M., Ekau, W., Peña, A., Dewitte, B., Oguz, T., Monteiro, P.M.S., Urban, E., Rabalais, N.N., Ittekkot, V., Kemp, W.M., Ulloa, O., Elmgren, R., Escobar-Briones, E., Van der Plas, A.K., 2010. Natural and humaninduced hypoxia and consequences for coastal areas: synthesis and future development. Biogeosciences 7, 1443-1467. doi:10.5194/bg-7-1443-2010

Zhang, Y., Singh, S., Bakshi, B.R., 2010. Accounting for Ecosystem Services in Life Cycle Assessment, Part I: A Critical Review. Environ. Sci. Technol. 44, 2232-2242. 